\title{
The influence of Musi river sedimentation to the aquatic environment
}

\author{
Achmad Syarifudin ${ }^{1, *}$ \\ ${ }^{1}$ Civil Engineering \& Environmental Department Faculty of Engineering, Bina Darma University, 30264 Palembang, Indonesia
}

\begin{abstract}
Musi river is the largest river in Palembang with a length of more than 750 kilometers. The sedimentation in the Musi river is commonly existed due to the high level meeting of velocity between the Musi river and the ocean in the Bangka Strait. The silting condition of Musi river is getting more severe due to the sludge growth that reach about $40 \mathrm{~cm}$ per month. In fact, the volume of sludge could reach 2.5 million $\mathrm{m}^{3}$. There are 13 silted points along the river shipping channel from the Boom Baru port to Bangka Strait. Four points are vulnerable due to the siltings reach up to $4 \mathrm{~m}$. This research was conducted by using the approach of software models MIKE 21 Flow Models. The results obtained from this study are the greatest speed direction occurred, elevation of the outer surface and total depth of water will contribute and effect to the free area for ships to perform well and safe movement. The other side will effect of the amount of sedimentation and the aquatic environment of the swamp area.
\end{abstract}

\section{Introduction}

Musi river is the largest river in Palembang with a length of more than 750 kilometers and an average width of 540 meters where the maximum width of 1,350 meters is located around the Kemaro island and the minimum width of 250 meters is located around the Musi II Bridge. Musi river has two islands, namely Kembaro (Kemaro) and Kerto islands. The three other major rivers are the Ogan river with an average width of 236 meters and the Keramasan river with an average of 103 meters [1].

The movement of sediment shows profound significance to river. The process of sediment transport and deposition can change the topography of the river bed [2]. The sediment deposition is a key factor to limit the river development and management [3]. The problem of sedimentation will have significant impacts on the operation lifetime of the river, the flood control capacity and the transportation.

Musi river is not only used by people around the the river, but also by big companies located along the Musi river. They use the Musi river to deliver the products and bring in the raw material through the vessel. There are many big ships and even giant pacing in the Musi river. Some companies located along the Musi river are PT. Pertamina, PT. Pupuk Sriwidjaja (fertilizer industry), Wilmar Group and the Port of Boom Baru, and Port at 35 ilir. The role of the Musi river is very vital and this is a pulse of Palembang city is now preoccupied by various problems. One of the problems is the river silting which continue to increase every year. This is surely become some disadvantageous to the Government of South
Sumatra Province, especially at this time of South Sumatra province being intensively attracts investors to invest in the business sector. Basically, sedimentation in the Musi river does include a high level of sedimentation caused by the current meeting between Musi river and ocean currents in the Bangka Strait.

Major sources of sludge in the country resulted from soil erosion and sedimentation are due to agricultural land occupation [4]. Common definition mentioned that siltation or siltification is the pollution of water by particulate terrestrial clastic material, with a particle size dominated by silt or clay.

Currently, the silting condition of Musi river is getting more severe because of the sludge that reaches about 40 $\mathrm{cm}$ per month. In fact, the volume of sludge could reach 2.5 million meter ${ }^{3}$. There are 13 silting points along the Musi river shipping channel from the Boom Baru port to Bangka Strait. Four points are very vulnerable because due to the silting reaches up to 4 meters. The location which is quite compress is from the northern Payung Island to the estuary, while the location of the worst silting among others is on the outside verge of the Jaran strait and the water groove of the sedimentation in the southern part of the Payung island reaches $7 \mathrm{~km}$, so the boat that crosses the groove of Musi river should be guided against the tide that occurs.

\section{Methodology}

This study was carried out with the modeling and simulation of flow patterns and sediment transport in water area of the Bangka Strait in position $2.07^{\circ}-2.38^{\circ}$

Corresponding author: syarifachmad6080@yahoo.co.id 


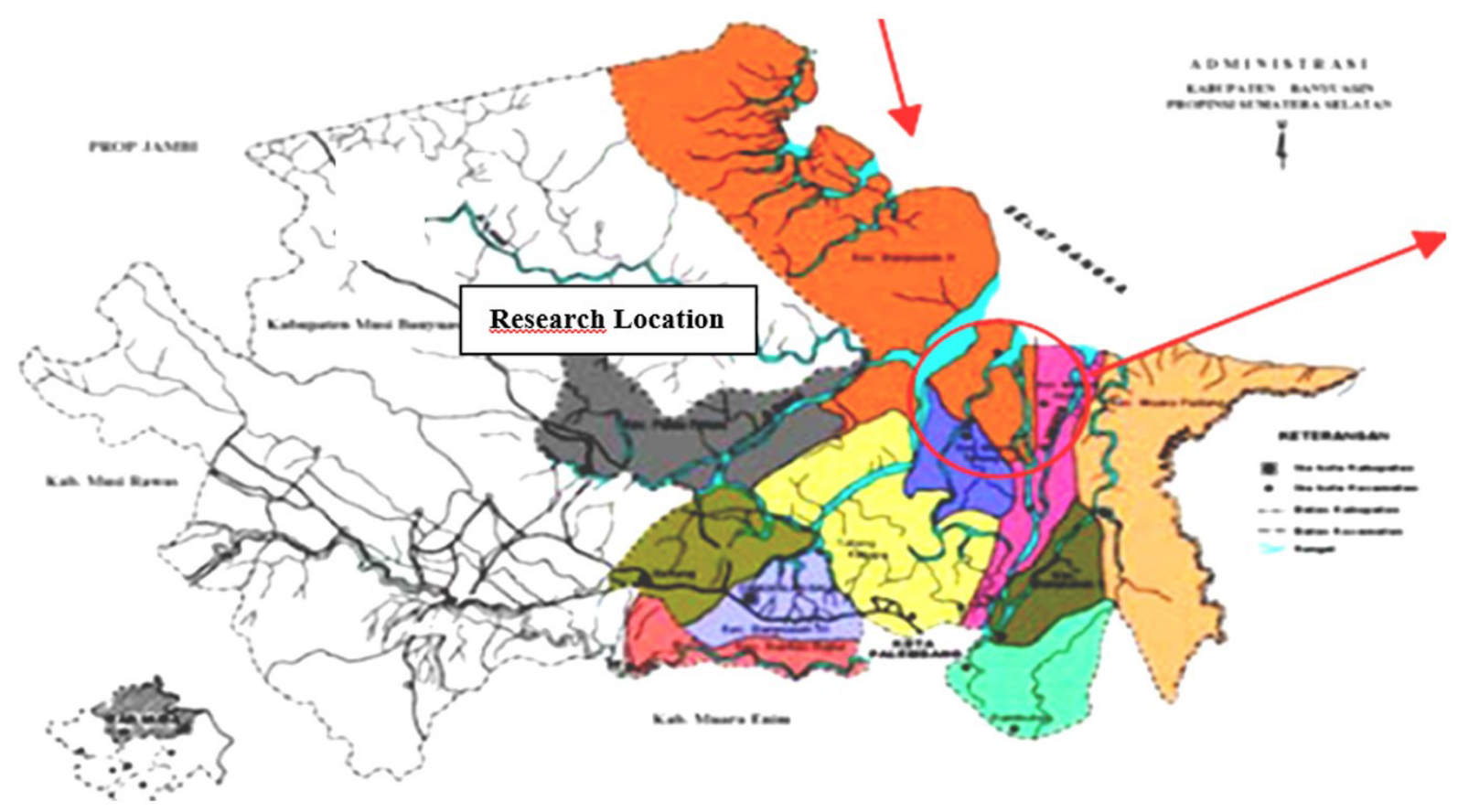

Fig. 1. Map of Research Location [5]

of South Latitude and $104.85^{\circ}-105.17^{\circ}$ of East Longitude. The research location is presented in Figure 1 .

\subsection{Hydro-climatological conditions}

Natural state of Palembang is relatively valley an tropical area, with an average temperature of most areas of Palembang $21^{\circ}-32^{\circ}$ Celsius, rainfall of 22-428 mm per year. Based on data from the Meteorological Station in 2003 the average air temperature range between $23,9^{\circ}$ $32^{\circ}$ Celsius, $24,04^{\circ}-32,60^{\circ}$ Celsius (2004), 22,44 ${ }^{\circ}-33,65^{\circ}$ Celsius (2005), 26,4 $-28,9^{\circ}$ Celsius (2006) and 21, $2^{\circ}-$ $35,5^{\circ}$ Celsius (2007). In 2007, the heaviest rainfall fell in April by the amount of rainfall is $540 \mathrm{~mm}$. While the air humidity in 2007 an average of $80 \%$, an average wind speed of $20 \mathrm{~km} /$ hours with the largest direction of the northwest, as well as the average air pressure at sea level at 1009 mbar and in the mainland amounted to 1007.5 mbar [4].

\subsection{Geological conditions}

Based on geological conditions, Palembang has a diverse relief consists of the ground in the form of a layer of alluvial and sandy loam. In the southern part of the city, the rock in the form of impermeable clay sand, north rocky sand impermeable clay, while the west rocky clay gravel, sand clay is impermeable to water-resistant. From the data obtained on the geological structure of the Jakabaring area folding structure is in the form of a number of anticline has a NW-SE trending axis. Their - The cross section of the Ogan River estuary to km 14.5 (Java canal) has a wide variation between 100-200 m with an average depth of $10 \mathrm{~m}$. A cross section Ogan River has a wide variation between $60-330 \mathrm{~m}$ with a multiplicity - the multiplicity leading to a muscular structure. Theoretically muscular structure will consist of four sets as follows:

- Perpendicular axis Sumatra Island

- Perpendicular direction of flow of the river Ogan

- Ogan or nearly parallel to the axis of Sumatra Island

- Directions NNE - SSW

- Direction NNW - SSE

\subsection{Hydrometric measurement}

From the results of measurements performed by consultant, the data obtained are:

- Fluctuations maximum tidal water level during spring tide in the estuary of the Ogan is $2.20 \mathrm{~m}$ and $2.40 \mathrm{~m}$ Ogan River estuary. In the period of spring tide ebb and flow of nature is a single daily, and gradually became mixed, eventually became semi - diurnal during the neap tide.

- Damping along the tidal section of the Ogan River estuary to the canal Java $(14 \mathrm{~km})$ is relatively small \pm 10 $\mathrm{cm}$ and on segment Ogan River from the mouth to the canal Java $(28 \mathrm{~km}) \pm 40 \mathrm{~cm}$.

- The current in the river is always moving downstream Ogan without ever reversed despite a speed variation is from 0.05 to $0.06 \mathrm{~m} / \mathrm{s}$ and large discharge is $60-500 \mathrm{~m}^{3}$ $/$ sec.

- In the Ogan River occurs reversing flow, the discharge variation between $110-120 \mathrm{~m}^{3}$ per secon. There is a transfer nearly all upstream river discharge into the river Ogan Ogan through the canal Java.

depth of the average between $2.2-7.8 \mathrm{~m}$

- The content of the sediment in the river Ogan ranged between 51-166 ppm at low tide and 16-56 ppm at high tide. The value in Ogan River is $36-116$ ppm at low tide 
and 52-136 ppm at high tide

- Bed material Ogan river and consists of silty sand, fine sand fraction to moderate with the $\mathrm{d} 50$ to the river Ogan ranged from 0.07 to $0.15 \mathrm{~mm}$ and for the river Ogan 0.15 to $0.32 \mathrm{~mm}$.[4]
The tools used in this research are as in Table 1 below.

\section{Tool and materials}

Tabel 1. List of tools used in the study

\begin{tabular}{|l|l|l|}
\hline \multicolumn{1}{|c|}{ No } & \multicolumn{1}{|c|}{ Name of Tools } & \multicolumn{1}{c|}{ Number of Uses } \\
\hline 1 & Stationery 2 pieces & Writing to recording data \\
\hline 2 & Computer (RAM 2 GB) 1 unit & Performing general modeling \\
\hline 3 & Printer 1 unit & Displaying form of report \\
\hline 4 & Software MIKE-21 Model, MS-Excel & Performing modeling and data processing \\
\hline 5 & Dongle (licensed program) 1 pieces & Activating the software MIKE-21 FM \\
\hline 6 & Laptop and Printer 1 pieces & Assisting to preparing reports \\
\hline
\end{tabular}

\section{Mike-21 flow model Simulation}

MIKE-21 Hydrodynamic Module (HD Module) is a mathematical model to calculate the hydrodynamic behavior of the water against a wide variety of styles functions. Particular wind conditions and water levels are specified in the open model of the boundary. HD module simulates the water level and the current differences in the various styles function in lakes, estuaries, and beaches.[5]

\section{Results and discussion}

\subsection{Output model hydrodynamics}

Therefore the boundary condition is discussed in the modeling, the results of global model output on the outside verge of the Musi river are as in Figure 2, 3 and 4. The greatest speed direction occurred on the Musi river bank ranges between 300-350 degrees.

The data used in the analysis are as shown in Table 2.

Table 2. Types and sources of data required

\begin{tabular}{|c|c|c|c|c|}
\hline No & Data properties & Data type & Sources & Units \\
\hline 1 & Tidal & Primary & Field & $\mathrm{m}$ \\
\hline 2 & Bathymetry & Secondary & Bakosurtanal / Pelindo & $\mathrm{m}$ \\
\hline 3 & The direction and speed of current & Primary & Field & $\left(^{\circ}\right) \& \mathrm{~m} / \mathrm{s}$ \\
\hline 4 & River capacity & Primary & Field & $\mathrm{m}^{3} / \mathrm{s}$ \\
\hline 5 & The direction and speed of wind & Secondary & $\mathrm{BMG}$ & $\left(^{\circ}\right) \& \mathrm{~m} / \mathrm{s}$ \\
\hline 6 & Base of Sediment & Primary & Field & $\mathrm{mm}$ or $\varnothing$ \\
\hline 7 & The concentration of suspended sediment & Primary & Field & $\mathrm{mm} / 1$ \\
\hline 8 & Discharge of sediment from the river & Primary & Field & $\operatorname{gram} / \mathrm{s}$ \\
\hline
\end{tabular}




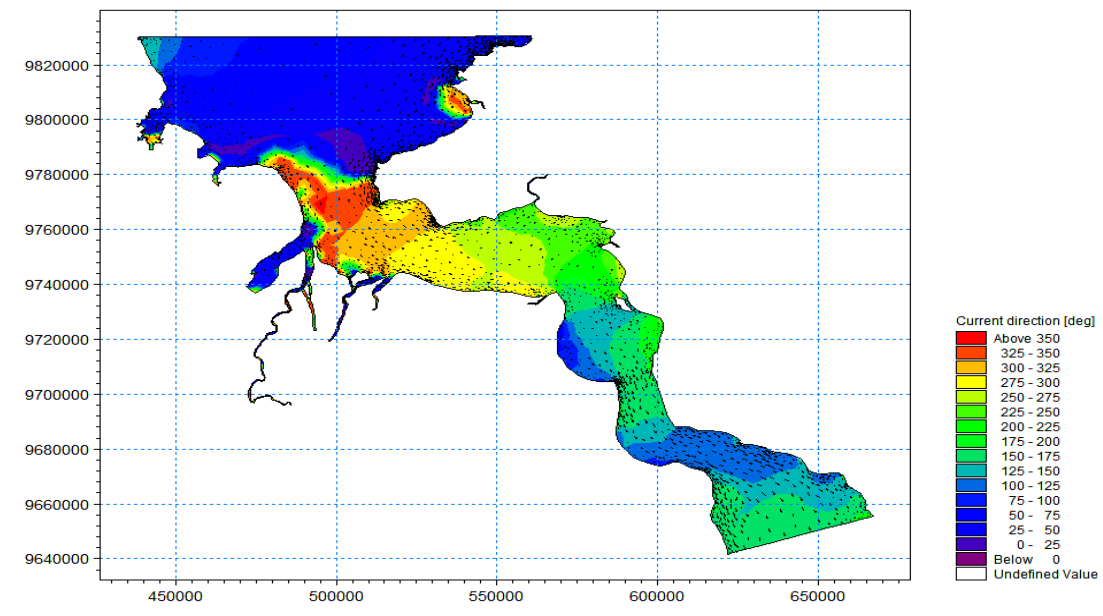

Fig. 2. The hydrodynamic model of the river water velocity direction.[5]

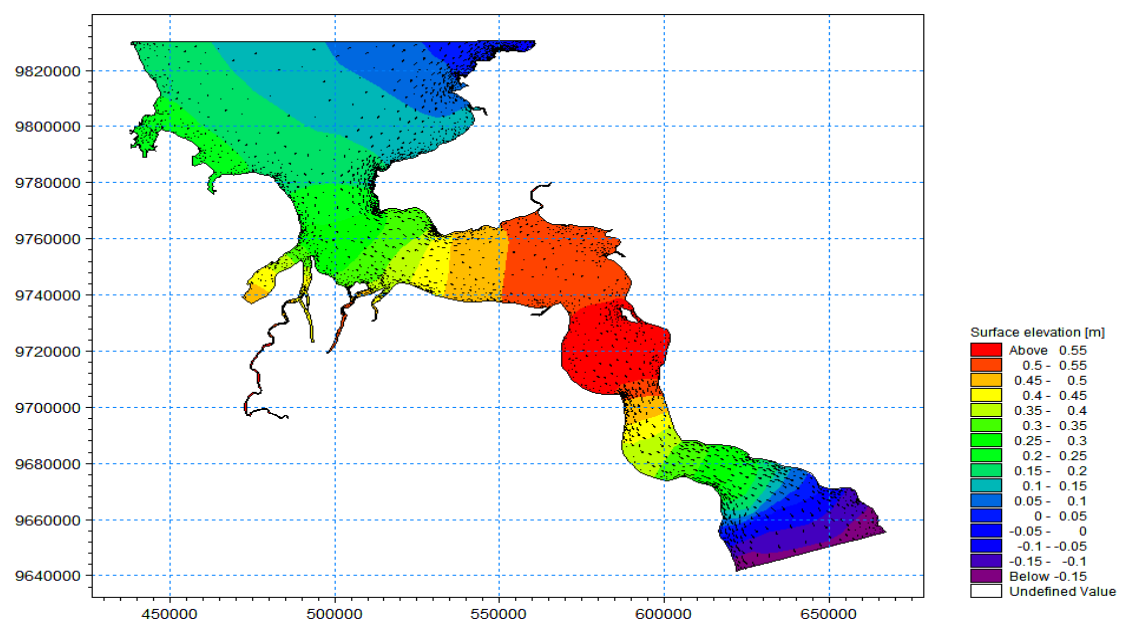

Fig. 3. Model hydrodynamic surface elevation Watersheds [5]

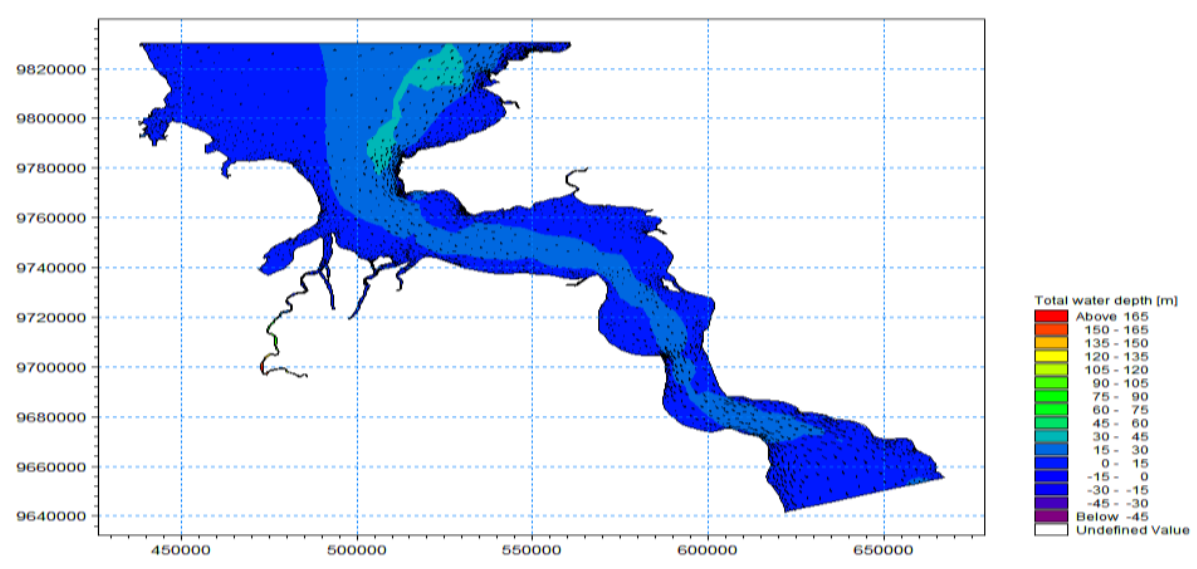

Fig. 4. The total depth of the hydrodynamic model of river flow [5]

Thresholds elevation of the outer surface of the Musi river ranges between $0.20 \mathrm{~m}-0.40 \mathrm{~m}$ will affect the free area for ships to perform well and safe movement.
The total depth of water occurs at $15-30 \mathrm{~m}$ and therefore contributes to the flow of the ship movement into the Musi river as a whole. 


\section{Conclusions and recommendations}

From the analysis of this study, we can conclude that the greatest speed direction occurred, elevation of the outer surface and total depth of water will contribute and effect to the free area for ships to perform well and safe movement. The other side will effect of the amount of sedimentation and the aquatic environmental of the swamp area $[4,9]$.

I would like to say thank you to Prof. Ir. H. Bochari Rachman, M.Sc, Rector of Bina Darma University, Prof. Dr. H. Zainuddin Ismail, MM, Vice Rector I and Dr. Sunda Ariana, MM, M.Ed, Vice Rector II of Bina Darma University who are pleased to give permission and assistance to the author, especially in the preparation of the data so that the paper can be completed.

\section{References}

1. AKNOP, Report. Department of Public Works Directorate General of Water Resources (2011)

2. S. J. Chen, Y. X. Yan, and Y. K. Li, "Spatial and temporal variations of suspended sediment deposition in the alluvial reach of the upper Yellow River from 1952 to 2007," Catena, vol. 92, pp. 3037, 2012.

3. Wanshun Zhang, Yanhong Xu, Yanru Wang, and Hong Peng, Modeling Sediment Transport and River Bed Evolution in River System, Journal of Clean Energy Technologies, Vol. 2, No. 2, April 2014

4. Fulazzaky, Mohamad Ali. "Challenges of integrated water resources management in Indonesia." Water
6.7 (2014): 2000-2020

5. BMKG, Hydro-climatology of Palembang (2007)

6. DHI Software, MIKE-21 Reference Manual, Danish Hydraulic Institute, Denmark (2007)

7. D G Wetlands and Beach, Report, Directorat General of Water Resources, Department Public Works (2006)

8. H. Sumarjo, R.H. Susanto, B. Schult, and F.X. Suryadi, Proceedings of the 9th Inter-Regional Confrence on water environment. Enviro water, Concept for Water management and multifunctional land uses in lowlands, Delft, the Netherlands (2006)

9. L. Hayde, Canal Designs, Lecture notes, IHE. Delft, The Netherlands (2007)

10. Land and Water Management Tidal Lowlands (LWMTL) South Sumatra Province, June 2004. Operation and Maintenance Network with water user associations (P3A), Rikjkswaterstaat, UNESCO-IHE, ARCADIS-Euroconsult in Cooperation with Regional Infrastructure, Ministry of Agriculture, Sriwijaya University and Local Government South Sumatra, Indonesia (2004)

11.F.X. Suryadi. Report: Regional Development Experience Swamp and O \& M Telang I. Land and Water Management Tidal Lowlands (2004)

12. A. Syarifudin. The 2nd International Conference on Informatics, Environment, Energy and Applications (IEEA 2013), Bali, Indonesia, March 16-17, 2013, JOCET (Journal of Clean Energy and Technology) Journal ISSN : 1793-821X Vol. 2, No. 1, January 2014. (2013)

13. A. Syarifudin, 5th ICIBA International conference on information technology \& Engineering Application, Palembang (2015) 